\title{
EXPLORAÇÕES GEOGRÁFICAS NAS COLEÇÕES FOTOGRÁFICAS: O PROJETO GÊNESIS COMO SOBREVIVÊNCIA DA CULTURA DA EXPLORAÇÃO
}

- LARA D'ASSUNÇÃO DOS SANTOS 1

1 Geógrafa. Mestre em Geografia pela Universidade do Estado do Rio de Janeiro. Doutoranda do Programa de PósGraduação em Geografia da Universidade do Estado do Rio de Janeiro. E-mail para contato: larad.assuncao@gmail.com.

Recebido em: 04/05/2019

Aprovado em: 10/10/2019

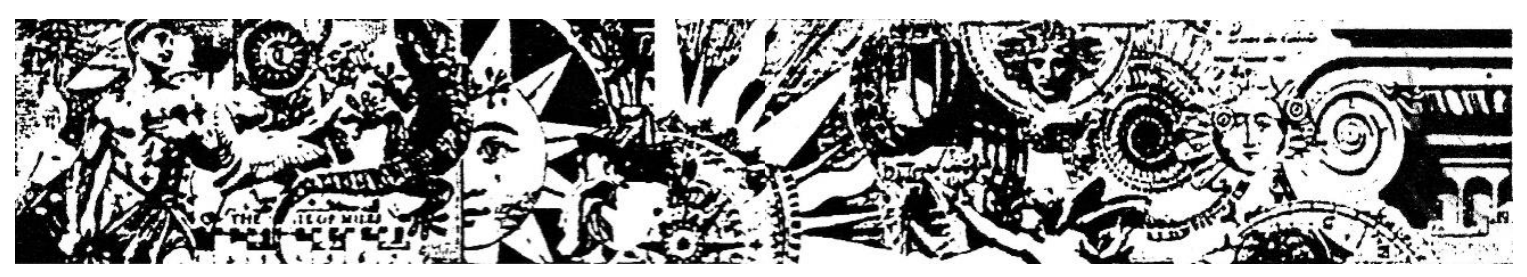

Resuma: Baseado nos três principais sustentáculos das coleçães fotográficas, ideia central, patracínio e circulação, o presente trabalho tomará a obra Cênesis, da fotógrafa brasileiro Sebastião Salgado, como um livro que traz à baila as práticas cientificas que vincularam gengrafia, viagens de expedição (ou exploraçãa) e fotografia. Primeiramente, a imagem será aqui apresentada como importante instrumento de apreensão do mundo. Por torná-lo inteligível, as coleçães fatográficas, garantiram larga audiência e permaneceram até os dias atuais, senda Gênesis uma delas. Pasteriormente, será proposta uma análise dos relatos da próprio autar e da mídia jornalística como farma de apresentar a sobrevivência da "cultura da exploração" não só por meio de imagens, mas também através das práticas. Palavras-chave: Fotografia, Gênesis; Sebastiãa Salgada; expediçãa geográfica; cultura da exploração 


\section{GEDGRAPHICAL EXPLDRATIINS IN PHOTOGRAPHIC COLLECTIONS: THE GENESIS PRDJECT AS EXPLDRATION CULTURE'S AFTERLIFE}

ABSTRACT: BASED IN THE THREE MAIN PILLARS OF THE PHDTOGRAPHIC CDLLECTIONS, CENTRAL IDEA, SPONSORSHIP AND CIRCLLATION, THE PRESENT WORK WILL TAKE THE BODK GÊNESIS, BY THE BRAZLLIAN PHOTOGRAPHER SEBASTIÃ̃ SALGADD, AS A BODK THAT UNITES THE SCIENTIFIC PRACTICES THAT LINKED GEDGRAPHY, EXPEDITIINN (DR EXPLORATION) TRIPS AND PHOTOGRAPHY. FIRSTLY, THE IMAGE WILL BE PRESENTED HERE AS AN IMPORTANT INSTRLMENT DF SEIZURE OF THE WDRLD. TD MAKE IT INTELLIGIBLE, THE PHOTOGRAPHIC CDLLECTIONS, GLARANTEED WIDE AUDIENCE AND REMAINED UNTIL THE PRESENT DAY, BEING GENESIS ONE OF THEM. SUBSEEUENTLY, IT WILL BE PRDPOSED AN ANALYSIS QF THE AUTHDR'S QWN REPDRTS AND THE JOURNALISTIC MEDIA AS A WAY TO PRESENT THE SUIRVIVAL OF THE "CULTURE OF EXPLDRATIIN" NDT ONLY THRDUGH IMAGES BUT ALSD THROUGH PRACTICES.

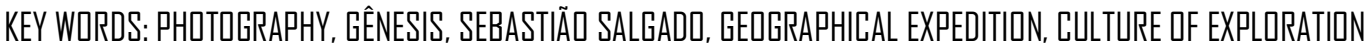

\section{EXPLDRACIONES GEOGRÁFICAS EN CDLECLIONES FOTOGRÁFICAS: EL PRDYECTO gENESIS CDMD SUPERVIVENCIA DE LA CULTURA DE EXPLDRACIÓN}

RESUMEN: BASADO EN LUS TRES PILARES PRINCIPALES DE LAS CDLECCIUNES FUTOGRÁFICAS, IDEA CENTRAL, PATROCINIO Y

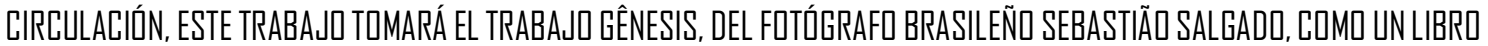

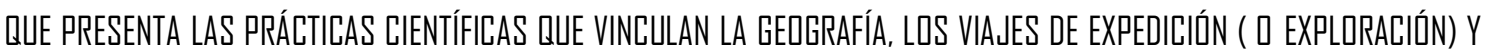
FOTOGRAFÍA. PRIMERD, LA IMAGEN SE PRESENTARÁ ADUÍ CDMU UN INSTRUMENTO IMPORTANTE PARA APREHENDER EL MUNDD. AL HACERLI INTELIGIBLE, LAS COLECCIONES FOTQGRÁFICAS HAN GARANTIZADO UNA AMPLIA AUDIENCIA Y SE HAN MANTENIDU HASTA NUESTRUS DÍAS, SIENDO GÉNESIS INA DE ELLAS. POSTERIDRMENTE, SE PRDPONDRÁ UN ANÁLISIS DE LIS PRDPIOS INFORMES DEL AUTOR Y DE LIS MEDIOS PERIODÍSTICDS CDMD UNA FDRMA DE PRESENTAR LA SUPERVIVENCIA DE LA "CULTURA DE EXPLORACIÍN" NQ SOLD A TRAVÉS DE IMÁGENES, SIND TAMBIÉN A TRAVÉS DE PRÁCTICAS.

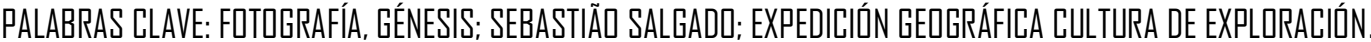

\section{Introdução}

A fotografia serviu de base à construção de um imaginário geográfico, principalmente a partir do aumento de sua circulação. Viagens, pesquisas e mapeamentos passaram a ter maior proveito após a criação do processo fotográfico e, no campo da geografia, a figura do explorador protagonizou os relatos de campo.

Ciente da importância dos exploradores e da circulação das imagens para o desenvolvimento da ciência geográfica tal como conhecemos hoje, o presente artigo tem como força motriz a permanência das práticas de exploração até os dias atuais. Em outras palavras, nos apropriaremos da obra Gênesis, de Sebastião Salgado (2013), com o objetivo de pensar a elaboração e a execução deste projeto à luz das viagens de campo geográficas, isto é, viagens que objetivavam mapear aquilo que era tido como exótico.

Devido ao papel central que a imagem desempenha na crítica social contemporânea com a emergência dos "estudos visuais" e da "cultura visual" como disciplinas acadêmicas, formou-se um ambiente que nos retira da passividade diante das 
imagens. Nesse sentido, arriscar realizar uma leitura geográfica de Gênesis está em concordância com o "pictorial turn" (MITCHELL, 1994).

A ideia de cultura da exploração (DRIVER, 2003) para compreender o projeto Gênesis ${ }^{2}$ como sobrevivência das expedições geográficas leva em consideração todo o aparato envolvido na produção, consumo e práticas 'reprodutivas', esta última ligada à circulação do conhecimento. Em linhas gerais, Gênesis, tal como nos primórdios da fotografia, foi pensado e elaborado no continente europeu. A equipe partiu de Paris em direção aos trópicos - a primeira parada da viagem que duraria oito anos foi Galápagos, no Equador - com uma ideia central em mente: registrar partes do mundo que ainda se encontram supostamente intocadas, como no dia do Gênesis.

O resultado consistiu em uma longa e extenuante viagem que culminou em três materiais de larga audiência: a exposição Gênesis, que esteve em museus e galerias das principais capitais do mundo, a coleção fotográfica de mesmo nome com quase 500 fotografias divididas em cinco grandes capítulos (Sul do Planeta, Santuários, África, Terras do Norte, Amazônia e Pantanal) e o documentário "O Sal da Terra", vencedor da Palma de Ouro no festival de Cannes e indicado ao Oscar.

Contando com fortes patrocinadores, dentre eles a Vale, Gênesis atingiu o meio escolar ao ser transformado em material didático nas Astúrias, Espanha. Não é a primeira vez que o material fotográfico de Sebastião Salgado é adaptado para escolas. No Brasil, foram feitas adaptações de Êxodos (2000) a partir de uma parceria entre o SESC de São Paulo e a Faculdade de Filosofia, Letras e Ciências Humanas da Universidade de São Paulo (FFLCH), onde foram impressos 2.000 exemplares distribuídos gratuitamente para professores e para o Movimento Sem Terra.

Desta maneira, o projeto Gênesis baseou-se nas três grandes bases de sustentação de uma coleção fotográfica já utilizadas desde as primeiras coleções, no século XIX: ideia, patrocínio e circulação. Esses três fatores auxiliarão na análise das semelhanças existentes entre as práticas existentes nas viagens de exploração e a obra Gênesis.

O tempo de viagem do autor (oito anos, passando por todos os continentes, exceto a Europa) e os tipos de fotografia presentes no álbum, como veremos adiante,

\footnotetext{
${ }^{2} \mathrm{~A}$ ideia do projeto Gênesis, surgiu quando o fotógrafo e sua esposa, Lélia, se depararam com a degradação da Mata Atlântica que recobria a fazenda e o entorno da propriedade do pai de Sebastião Salgado. Esse projeto foi apoiado pela Vale, empresa que cedeu as primeiras mudas e os primeiros trabalhadores para recuperar a área, hoje, Instituto Terra (SALGADO, 2014). Foi por meio dessa parceria que o projeto teve início e por causa dela que tantas críticas foram direcionadas à obra.
} 
apresentam de antemão Gênesis ligado às ricas tradições da geografia, o que não significa dizer que nos ateremos apenas a referenciais desta ciência. $\mathrm{Na}$ primeira parte nos apropriaremos das colocações do antropólogo Bruno Latour (2015 [1986]), para quem as técnicas devem funcionar como móbiles imutáveis, ou seja, permitindo-nos juntá-las e deslocá-las de acordo com nossos interesses. O objetivo é refletir acerca do potencial das coleções fotográficas ao nos apresentarem o mundo de forma convincente por conta de sua verossimilhança.

$\mathrm{Na}$ segunda parte, utilizaremos aportes da ciência geográfica que em seus primórdios já percebia o potencial da fotografia, sobretudo quando atrelada ao discurso. Essa união entre imagem e discurso foi utilizada para reiterar práticas colonialistas alegando uma necessária "alfabetização do olhar”. O uso desse material foi feito a partir dos lanterslides preparados pelo geopolítico Halford Mackinder, onde ele instruía o fotógrafo a representar as características nativas do país e de seu povo (RYAN, 1997, p. 209).

Como forma de romper o caráter de verdade inquestionável das imagens, a terceira parte conta com aproximações visuais de fotógrafos de diferentes séculos. Nesta seção levaremos em consideração o contexto em que foram feitas, por quem foram feitas e como foram utilizadas. Essas aproximações visuais serão de suma importância para a leitura do projeto Gênesis como uma possível sobrevivência (afterlife ${ }^{3}$ ) da cultura da exploração, haja vista que esta não se expressaria apenas nas imagens, mas também nas práticas.

Tentaremos ponderar Gênesis para além da suposta verdade trazida em suas fotografias, demonstrando que determinadas práticas são sintomáticas. Se as imagens guardam fenômenos culturais complexos, visões de mundo que precisam ser primeiramente criticadas e não assimiladas como algo pronto e encerrado em si mesmo (FLUSSER, 2011 [1983]), as posições em que os indígenas são colocados, o olhar para a câmera e o lugar da fotografia serão levados em consideração nas montagens expostas mais adiante.

\footnotetext{
${ }^{3}$ Nos escritos de Geography Militant (DRIVER, 2003), a sobrevivência (afterlife) da Geografia Militante (momento em que ainda havia espaços em branco nos mapas, isto é, territórios a serem explorados) está presente não só nas imagens, como também nas práticas, sejam elas reprodutivas ou não. As montagens que serão mostradas mais adiante têm como intuito destacar as semelhanças visuais, enquanto os relatos sobre o autor e seus patrocínios têm como objetivo trazer as histórias por trás das imagens, outra forma de sobrevivência para além do visual. 


\section{Imago Mundi: a percepção do mundo por meio das representações imagéticas}

Antes do surgimento do processo fotográfico no século XIX a narrativa visual já traduzia nossa ânsia por apreender o mundo, pois esteve presente nas cosmologias, cosmografias, mapas, pinturas ou mesmo nas narrativas dos diários de viagem. Por apresentar característica de verossimilhança, a fotografia tornou-se uma ferramenta indispensável, não só por produzir imagens de mundo, mas por ser um móbile imutável (Latour, 2015 [1986]), isto é, uma técnica que permitiria juntar, sobrepor e circular seus resultados. Segundo Bruno Latour,

As 'coisas' que você juntar e deslocar tem de ser apresentáveis de uma só vez para aqueles que você deseja convencer e que não foram lá. Em soma, você precisa inventar objetos que tenham a propriedade de ser móbiles, mas também imutáveis, apresentáveis, legíveis e combináveis com os outros (LATOUR, 2015 [1986], p. 7).

O cerne deste movimento recai sobre a ideia de cultura visual dominante, que é assim classificada porque, dentre outros fatores, têm o poder de expressar como os países que detêm as técnicas de representação veem o mundo. Eles teriam, então, a aptidão de apresentar coisas ausentes que jamais foram ou serão presentes para os espectadores das demais culturas (ALPERS, 1999), impondo certo domínio sobre o que deve ser e o que é visto por elas.

É notório que se há uma cultura visual dominante que detém importantes técnicas de representação do espaço em que vivemos, por detrás dela existe um objetivo maior do que apenas representar. Este objetivo perpassa pela garantia do monopólio do conhecimento das regiões - tal como nas cartas marítimas elaboradas e utilizadas pelas companhias de comércio que eram guardadas a sete chaves (ALPERS, 1999) - até a padronização, por assim dizer, das instruções de viagem (Hints to Travellers) feitas pelas Sociedades de Geografia, que contavam com algumas diretrizes para que o viajante pudesse saber quais informações deveria trazer.

Desta maneira, a cultura visual teria sido "ditada" por aqueles que dominavam as formas e as técnicas de representação do mundo. Retratar o mundo segundo suas visões possibilitou os estudos sobre os "tipos de raça", o conhecimento dos espaços e de seus habitantes, cujo objetivo era identificar, ordenar, categorizar para melhor dominar. 
Todos esses fatores reforçaram a superioridade cultural europeia, elemento-chave para, inclusive, justificar seu papel colonial (SCHWARTZ, 1996).

O início da popularização da fotografia deu-se a partir da possibilidade de fazer cópias do mesmo negativo durante a década de 1850. Neste momento de expansão colonialista dos países europeus o homem moderno pode conquistar e domesticar a natureza (BORGES, 2008), bem como diversificar os registros de diferentes lugares do mundo, tornando-o "colecionável”. Além de estarem presentes nos álbuns fotográficos, as fotografias "narravam” as realidades locais através das exposições em galerias.

Como exemplo de que as imagens nos promoviam a ilusão de conhecermos o mundo por completo, vale destacar a importância das Exposições Universais realizadas a partir do ano de 1851 . Tais exposições reuniam num mesmo espaço representações das regiões em expansão (países europeus e Estados Unidos), regiões sob regime colonial e regiões distantes (do ponto de vista imperialista), promissoras de matérias-primas, como a América Latina (BARBUY, 1996, p. 21 1). Uma representação do mundo que mostrava por meio das imagens expostas o exotismo dos orientais e fortalecia a interdependência econômica (BARBUY, 1996).

Desta forma, a invenção da fotografia não se deu por acaso. Ela é fruto dos novos anseios surgidos com a sociedade moderna e, portanto, sempre esteve envolvida numa comercialização ditada pela lógica do mercado. A tecnologia fotográfica atuava então, como um veículo a serviço do "deslumbre da monumentalidade", fixando em papel as realizações materiais das nações capitalistas (MUAZE, 2009).

As Exposições Universais evidenciam que a cultura visual dominante, é assim denominada devido ao domínio das técnicas de representação e circulação por seus inventores, além de outros fatores de suma importância como a linguagem, os discursos e a experiência inerente às imagens. As visões de mundo que circulavam eram as dos países centrais, de instituições geográficas, de filantropos europeus dispostos a pagar por grandes projetos de viagem, de revistas como a National Geographic (lançada em 1888 pela National Geographic Society) e de outras sociedades de geografia, como a Royal Geographical Society (RGS)4 e a Société de Géographie, todos representantes de uma cultura visual dominante (ALPERS, 1999).

No que concerne a ciência geográfica, o geógrafo inglês Halford Mackinder (1861-1947) durante toda sua trajetória primou por uma visão estratégica global

\footnotetext{
${ }^{4}$ Sobre o papel da Royal Geographical Society, ver James Ryan (1997) e Felix Driver (2003). 
extremamente ligada às visualidades. Percebendo as potencialidades presentes nas imagens, Mackinder criou em 1902, o Visual Instruction Committee of the Colonial Office (COVIC) com o intuito de instruir visualmente as crianças (uma espécie de alfabetização visual) para fazê-las entender por meio de slides o que eram as outras partes do mundo (MACKINDER, 1911). Tais projeções eram utilizadas nas escolas do Reino Unido e também nas colônias inglesas (RYAN, 1997).

Mackinder via a geografia como a disciplina do império por ser uma forma especial de visualização que ele chamou de "pensar geograficamente" (MACKINDER, 1911). O geógrafo James Ryan esclarece que há a existência de uma geopolítica da imagem fortemente exercida pelo Império Britânico, sobretudo nos anos em que a COVIC esteve funcionando, entre 1902 e 1911. Segundo o autor, o exotismo, as ideias de superioridade de raças e o evolucionismo trazidos através das fotografias de Hugh Fisher - fotógrafo-artista que trabalhava junto a Mackinder — eram verdadeiras peças de propaganda colonial (RYAN, 1997) que por muitos anos serviram para legitimar esse tipo de discurso.

\section{Imago Collection: coleções fotográficas ao longo dos séculos}

Abordar as explorações geográficas focando mais diretamente na cultura da exploração significa perpassar por questões políticas bastante polêmicas sobre quem financia (ou comissiona) os projetos, quem detém o controle desses arquivos, quem tem acesso a eles e quem teve acesso quando do momento da publicação.

Partindo de algumas comparações entre as coleções fotográficas Gênesis, de Sebastião Salgado (2013), Trésors Photographiques de la Société de géographie (2007), Les Archives de la Planète (Arquivos do Planeta - 1909-1931) e Excursions Daguerrienes: Vues et monuments les plus remarques du globe (Excursões daguerrianas: as paisagens e os monumentos mais notáveis do mundo - 1840-1844), pode-se dizer de antemão que todas tiveram o propósito de apresentar o mundo ao homem ocidental, de servirem como mapas do mundo. Apenas o Les Archives de la Planète não foi organizado no formato de álbum, mas constitui uma preciosa coleção fotográfica em exposição permanente na França e utilizada em manuais escolares de geografia.

O primeiro deles, Excursions Daguerrienes: Vues et monuments les plus remarques du globe (Excursões daguerrianas: as paisagens e os monumentos mais notáveis do mundo - 1840-1844), apesar de ter sido feito a partir da daguerreotipia e, por isso, pouco 
reproduzido, foi o primeiro fotolivro a trazer narrativas de viagem. Elaborado a partir da reunião de imagens de viagens de exploração, sua publicação de Noël Marie Paymal Lerebours (1807-1873) ocorreu entre 1841 e $1843^{5}$, em Paris, simbolizando a nova possibilidade do homem comum: correr o mundo e fotografá-lo.

Outro material de grande visibilidade é a coleção Archive du la Planète (Arquivos do Planeta - 1909 - 1931). Financiado pelo filantropo Albert Kahn, o projeto constituía em uma grande obra geográfica, cuja direção científica entre 1912 a 1930 foi feita pelo geógrafo Jean Brunhes (1869-1930), professor de Geografia Humana do Collège de France. O "Arquivos do Planeta" resultou numa das mais importantes coleções fotográficas porque visava "o inventário das diferenças de um mundo em vias de urbanização ou o registro dos costumes locais em vias de desaparecimento" (ANGOTTISALGUEIRO, 2005, p. 23), objetivos extremamente ligados às ciências humanas que tanto caminharam ao lado da formação das coleções fotográficas.

Riquíssimo álbum organizado por Oliver Loiseaux, Trésors photographiques de la société de géographie (LOISEAUX, 2007), sublinha o uso e interesse das Sociedades de Geografia pelas imagens fotográficas. Curador-chefe do departamento de mapas e planos da Biblioteca Nacional Francesa e encarregado das coleções da Sociedade Geográfica Francesa, Loiseaux, de forma bastante perspicaz selecionou e compilou as fotografias do arquivo, muitas delas frutos de doações de seus próprios membros.

A peculiaridade de Trésors Photographique frente às demais coleções aqui abordadas encontra-se no fato de ser um álbum composto por fotografias do século XIX reunidas durante o século XXI. Ela ressalta, portanto, o caráter mnemônico da fotografia.

Após o preenchimento dos espaços em branco dos mapas resultantes das viagens de exploração só restaria a memória daquilo que fora visto. Mackinder, na conferência de 1904, demonstrava preocupações em relação ao "fechamento" dos mapas, denominado por ele como o fim da "era de Colombo" (MACKINDER, 1904 apud NOVAES, 2010). Era uma fase de crise para a geografia devido ao fim da exploração geográfica que traria consigo a inevitável decadência do heroísmo dos exploradores.

Em vista disso, a Royal Geographical Society, associada à exploração desde 1830, trabalhou arduamente para dissipar a noção de que a época de ouro das explorações havia

5 Informação presente no site do Musée Français de la Photographie. http://expositions.museedelaphoto.fr/mod_webcms/content.php?CID=LQ1673C [Acesso em julho de 2015]. 
passado. Assim, passou a promover desafios como o chamado "Ainda Desconhecido" (“Still Unknown”), onde patrocinava expedições oficiais e ajudava entusiastas amadores. Os polos, em particular, ofereciam fronteiras desconhecidas a serem exploradas, e a Europa e América do Norte objetivavam desbravá-las. O resultado era imagens para o lanterslide show e um brilhante livro ilustrado, isto é, sinais de uma modernidade degenerada onde o explorador geográfico não correspondia mais à figura de herói desbravador.

O uso da fotografia dentro da sala de aula foi a característica distintiva de Mackinder na educação geográfica. A COVIC (Visual Instruction Committee of the Colonial Office) enviava artistas-fotógrafos para viagens ao redor do mundo com o objetivo de obter imagens imperiais adequadas ao uso em lanternas para palestras (lanterslides) e livros didáticos. Em termos de enquadramentos geopolíticos, a exploração do início do século $\mathrm{XX}$, em muitos aspectos, viu a continuação das práticas de exploração, prospecção e conquista (DRIVER, 2003).

Se, no início do século XX, Mackinder já percebia a crise das explorações geográficas, como poderia Gênesis apresentar larga audiência em pleno século XXI, uma época marcada por ferramentas que permitem a visualização do mundo, onde nada mais seria novo aos nossos olhos?

Em primeiro lugar, uma obra vasta e complexa quanto Gênesis não pode ser compreendida de forma apartada de seu autor. Sebastião Salgado vem impactando o campo da fotografia nos últimos trinta anos com uma estética marcada por imagens em preto-e-branco e acentuado conteúdo político, tal como se pode observar em suas obras anteriores. Nelas, seu olhar crítico consagrou-se ao registrar os dramas humanos associados à economia capitalista, tais como migrações forçadas, disputas pela terra, exploração do trabalho, fome e violência, propagando significativa inquietação social ${ }^{6}$.

Assim como os álbuns dos séculos XIX e XX que retratavam o que foi visto nas viagens de exploração, Gênesis (2013) contou com diversos patrocínios para que o projeto fosse levado adiante, alguns deles bastante controversos, inclusive. Para compreender as contradições que envolvem seus registros, seus patrocínios e as

\footnotetext{
"Em "Trabalhadores: Uma arqueologia da era industrial" (1993), o fotógrafo parte do princípio que se todo produto resulta da combinação entre matéria-prima, capital e trabalho, este último seria o mais importante e estaria em vias de desaparecer. Na mesma esteira de raciocínio embasada na geopolítica da produção, o próximo projeto de Sebastião Salgado teve início a partir de sua percepção sobre a grande migração do campo (já em vias de industrialização) para a cidade. Denominado "Êxodos" (2000), a obra conta a história de todas as populações obrigadas a deixar suas casas por razões econômicas - que favorecem uma minoria, enquanto a maioria se torna miserável - religiosas, climáticas ou políticas. 
influências destes em seu discurso é preciso identificar Gênesis como um fotolivro dono de uma poderosa narrativa.

A ideia central do fotolivro surgiu após herdar a fazenda de seu pai, em Aimorés (MG), no Vale do Rio Doce. Ao deparar-se com uma enorme devastação do vale onde nasceu e cresceu, o fotógrafo dedicou-se a estabelecer contatos para reflorestar o local. Dono de prêmios importantes da fotografia, o nome de Sebastião Salgado possui peso suficiente para pleitear e conseguir patrocinadores. Apoiado pela Vale, empresa que cedeu as primeiras mudas e os primeiros trabalhadores para recuperar a área, hoje, Instituto Terra, Salgado testemunhou o poder de resiliência da natureza, mote de Gênesis.

Dentre tantos outros patrocínios ${ }^{7}$ enumerados por Sebastião Salgado em seu livro autobiográfico "Da minha terra à Terra" sem dúvidas é por conta da Vale que o fotógrafo recebe mais críticas. De fato, soa de forma contraditória que um fotógrafo dotado de um olhar engajado (MAUAD, 2008) aceite o patrocínio de uma mineradora para fotografar aquilo que ainda não foi degradado (por ela ou por empresas similares).

Nessa dinâmica de patrocínios e críticas a eles, também é possível identificar características da sobrevivência da cultura da exploração em Gênesis, uma vez que esta é entendida como um conjunto de práticas que envolvem a mobilização de pessoas e recursos, especialmente equipamentos, publicidade e autoridade (DRIVER, 2003). Percebendo a necessidade de buscar novas representações, se apegou ao discurso ambientalista como mola mestra de sua nova obra.

Embora sejam mais prestigiados atualmente, os fotolivros existem quase desde o nascimento da própria fotografia. Gerry Badger afirma que é neste tipo de publicação que a fotografia expressa seu verdadeiro potencial criativo: uma arte literária e narrativa, entre o filme e o romance (BADGER, 2015). Mas, para alcançar notoriedade, o fotolivro deve conter um excelente trabalho, trazer o mundo conciso dentro do próprio livro, contar com um projeto gráfico que enalteça o que está sendo tratado e, por fim, um conteúdo que mantenha o interesse do leitor (GOSSAGE apud BADGER, 2015). Badger complementa que o fotolivro não se constitui simplesmente de um punhado de fotos feitas por um único e mesmo fotógrafo, não importa quão boa cada uma delas seja. $\mathrm{O}$

\footnotetext{
${ }^{7}$ Segundo Salgado (2014, p. 63), dentre os patrocinadores que mais contribuíram estão: o governo federal brasileiro, bem como dos governos dos estados de Minas Gerais e Espírito Santo. Também o Fundo Brasileiro para a Biodiversidade, que operava ao lado do Banco Mundial, empresas e fundações brasileiras e, por fim, receberam auxílio enorme de empresas e fundações francesas e monegascas; do governo das Astúrias e da Generalitat Valenciana, na Espanha; na Itália, da Emília-Romanha, da província de Roma, do Friul e da cidade de Parma.
} 
grande fotolivro precisa ter um tema, uma ideia abrangente, e deve funcionar, como me disse Gossage numa conversa, como “um mundo próprio” (BADGER, 2015, n.p.).

Para sustentar uma forte ideia central e um projeto gráfico bem elaborado, Salgado conta com a equipe da Amazonas Images ${ }^{8}$, misto de escritório, ateliê e usina de ideias que só existe em função de Salgado. O fotógrafo declara que antes mesmo de ter terminado todas as reportagens, a exposição das fotos de Gênesis já estava programada em grandes museus, nos quatro cantos do mundo (SALGADO, 2014, p. 66).

Para além das bases de sustentação de um fotolivro (ideia, patrocínio e circulação da obra), é provável que os reais motivos não se devam apenas ao business porque a audiência das coleções está atrelada a um valor subjetivo, o que caracterizaria a recorrência como algo sintomático. Os sintomas estariam de acordo com a época em que as fotografias foram feitas. Desde os primeiros registros narrativos e imagéticos das viagens de exploração havia uma ânsia de apreensão do mundo que nos move e nos aflige até os dias atuais, mas por motivos distintos.

Refletindo sobre o advento da fotografia, conscientemente ou não, os homens começaram a duplicar o mundo com mais veemência justamente no momento em que a paisagem humana entrou num ritmo vertiginoso de transformação: enquanto as formas de vida biológicas e sociais são destruídas em um curto espaço de tempo, um aparelho se tornou acessível para registrar aquilo que estaria em vias de desaparecer (SONTAG, 2004 [1977], p. 26).

A grande percepção de Sebastião Salgado em Gênesis foi justamente apropriarse das principais bases supracitadas entrelaçando-as às aflições humanas. $\mathrm{O}$ homem do século XXI, ao mesmo tempo em que tem dimensão do quanto degrada o mundo, não consegue deixar de fazê-lo. Encontra-se completamente imerso nas tecnologias que enaltecem o instantâneo, a efemeridade das coisas, das relações, dos vínculos.

Complementarmente, durante as viagens de Gênesis, Sebastião Salgado diz ter se apercebido da necessidade de voltarmos à natureza no sentido de priorizar o tempo dela, dos seus ciclos (SALGADO, 2014). Um discurso interessante e em bastante

\footnotetext{
${ }^{8}$ Atualmente, com a carreira extremamente estabilizada, Salgado conta desde 1994 com uma pequena equipe, mas de grandes nomes, à frente da Amazonas Images. À época, ele renunciou pertencer aos quadros da almejada agência Magnum para montar uma equipe de profissionais competentes e confiáveis que ficasse em sua retaguarda enquanto ele corria o mundo. Esse formato deu tão certo que hoje em dia Sebastião Salgado está entre os 3 fotógrafos mais bem pagos do planeta e tornou-se o segundo fotógrafo do mundo a pertencer à prestigiosa Academia de Artes e Ciências dos Estados Unidos. O primeiro foi Henri Cartier-Bresson, em 1974 (HARAZIM, 2016). 
sintonia com a sua época, mas também adotado pelas grandes empresas, por sinal, as que mais degradam sob a roupagem do desenvolvimento sustentável. ${ }^{9}$

A ideia central é, portanto, um importante passo para garantir a audiência da coleção fotográfica, e consiste num primeiro diálogo entre Gênesis e as práticas da cultura da exploração. Desde a criação da fotografia as coleções eram montadas a partir da seleção e justaposição das imagens feitas durante as viagens de exploração financiadas por mecenas, sociedades de geografia, dentre outros, que ditavam através de instruções e contratos o que deveria ser trazido.

\section{Sobrevivências da cultura da exploração: Sebastião Salgado em Gênesis}

As sobrevivências da cultura da exploração não estão presentes apenas nas imagens de Gênesis, mas também nas práticas, sejam elas reprodutivas ou não (DRIVER, 2003). As mais evidentes são o tempo de viagem para a realização do projeto e a característica inóspita e exótica das regiões fotografadas. Tal como os viajantes de antigamente que eram financiados por mecenas e pelas Sociedades de Geografia, Salgado também é comissionado e seus desejos estão de acordo com grandes empresas.

Seu hall de prêmios e títulos importantes da fotografia lhe deram poder de barganha com patrocinadores por todo o mundo, mas também lhe garantiram um significativo número de críticas. Uma vez que as práticas ligadas à cultura da exploração aparecem em Gênesis na forma de sobrevida, pode-se concluir de antemão que a larga audiência da obra não viria do ineditismo das fotografias, mas de nossa tendência a reciclarmos imagens como se fossem novas, inéditas (SONTAG. 2004).

O segundo elemento-chave dos fotolivros, o patrocinador, geralmente convoca os fotógrafos a realizarem a tarefa de registrar o mundo em via de desaparecer, mas algumas vezes eles mesmos, os patrocinadores, apressam seu desaparecimento. É

\footnotetext{
${ }^{9}$ A Vale, companhia de mineração brasileira, é considerada inimiga número um do meio ambiente. A fama veio do envolvimento dessa empresa nas obras de Belo Monte. Segundo ativistas, a usina vai inundar cerca de $500 \mathrm{~km}^{2}$ da floresta amazônica e desalojar tribos indígenas como as que aparecem nas fotos de Gênesis. Christian Poirier, ativista da ONG Amazon Watch, afirma que o financiamento da Vale à exposição é "lavagem verde", ou seja, um mero discurso da empresa com o intuito de propagar práticas ambientais positivas, quando na verdade sua atuação é degradadora. Financiar um projeto como o Gênesis, liderado por um fotógrafo engajado e visto como denuncista, foi para as empresas uma excelente troca: investese capital e tem-se uma imagem pública confiável. Matéria do jornal The Independent, em 17/07/2013, cujo título é "The natural world, photographed by Sebastião Salgado - sponsored by a corporation that's despoiling the Amazon". Disponivel em: [http://www.independent.co.uk/artsentertainment/art/news/the-natural-world-photographed-by-sebasti-o-salgado-sponsored-by-acorporation-thats-despoiling-the-8714748.html]. Acesso em: dezembro de 2016. 
justamente o que ocorre com Sebastião Salgado. Sua cidade de nascimento, Aimorés (MG) fica localizada no Vale do Rio Doce, nome da companhia mineradora local (hoje, apenas Vale) que é proprietária das maiores minas de ferro do mundo. Esta empresa foi a primeira a recuperar a degradação da Mata Atlântica que recobria a fazenda e o entorno da propriedade do pai de Sebastião Salgado cedendo as primeiras mudas e os primeiros trabalhadores, onde se localiza o Instituto Terra.

Nessa dinâmica de patrocínios e críticas a eles, também é possível identificar características da sobrevivência da cultura da exploração em Gênesis, uma vez que esta é entendida como um conjunto de práticas que envolvem a mobilização de pessoas e recursos, especialmente equipamentos, publicidade e autoridade (DRIVER, 2003).

Além disso, ao mesmo tempo em que destaca as preocupações típicas de um cidadão da segunda metade do século XX e início do século XXI, buscando mitigar as rápidas e duras transformações advindas do modelo capitalista, Salgado contraditoriamente assume uma postura que o aproxima dos primórdios da fotografia: o fotógrafo admite ter modificado o cenário natural da fotografia. De acordo com a sua colocação, seu objetivo era:

(...) retratar esses povos [as tribos presentes em Gênesis] o mais próximo possível do seu estilo de vida ancestral. Alguns se vestem com roupas de segunda mão distribuídas por grupos evangélicos, mas eu queria mostrar os trajes cerimoniais e os costumes tribais de que eles mais se orgulhavam e de que, dentro de algumas décadas, poderão apenas restar as fotografias. Cedo ou tarde, o mundo moderno irá atingi-los — ou serão eles a procurá-lo. Eu quis captar o mundo que está desaparecendo, uma parte da humanidade que está prestes a acabar, mas que, no entanto, ainda vive, de muitas maneiras em harmonia com a natureza (SALGADO, 2013, p.8).

Foi preferível modificar o que foi visto para convencer os espectadores da existência da harmonia e do frescor primitivo, conforme se referiam os primeiros exploradores. Somando a proposta central de Gênesis à elevada influência de Salgado, solicitar aos membros da tribo que usem seus trajes originais para serem fotografados é forçar que guardemos em nosso imaginário as imagens que se aproximam do dito primitivo, ainda que não o seja mais.

Enquanto as primeiras coleções fotográficas tinham a capacidade de apresentar o mundo ao homem, a coleção fotográfica de Sebastião Salgado, antes de "apresentar" o mundo ao homem, utilizou dados e imagens veiculados pela mass media como preciosas 
informações para a montagem de seu projeto. Informado pela ONG de preservação ambiental Conservation International, o fotógrafo foi estimulado a registrar o que se encontra conservado: parte dos $75 \%$ da Amazônia, locais de difícil acesso como as terras frias do Sul e do Norte, os desertos e as terras situadas a mais de 3 mil metros de altitude.

Já em consonância com a ideia central de Gênesis, cuja primeira viagem foi feita no ano de 2005, Sebastião Salgado esteve presente em debates acalorados ocorridos no Fórum Social Mundial, em 2003. Nas palavras do autor, antes de Gênesis ele havia fotografado uma única espécie: o homem. Agora, dedicando-se à natureza intocada, precisou aprender a trabalhar com outras espécies (SALGADO, 2014).

Propagados pela mídia nacional e internacional, a ideia de natureza intocada dotada de uma beleza que compensaria os esforços do fotógrafo, conforme pode-se observar na montagem adiante (fig. 1)., aproxima Sebastião Salgado de um típico viajante explorador em busca do desconhecido, do virgem, do intocado, uma espécie de Messias, conforme aponta seus relatos.
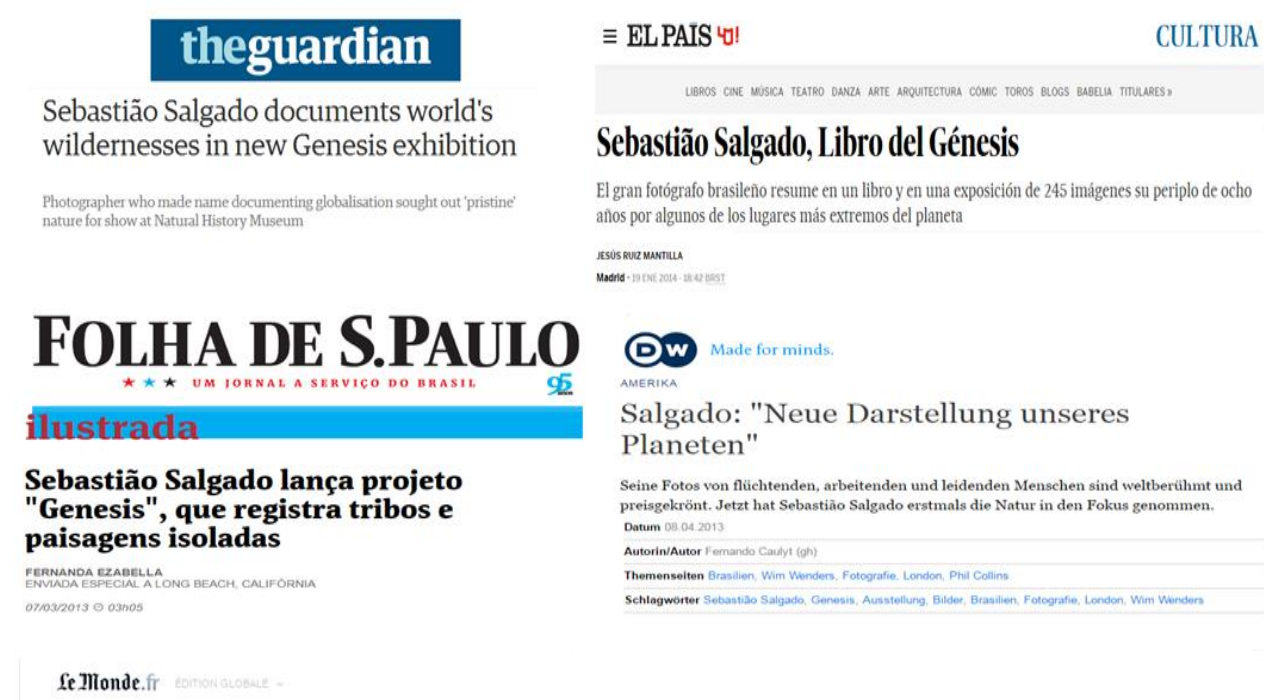

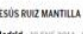


Planeten"
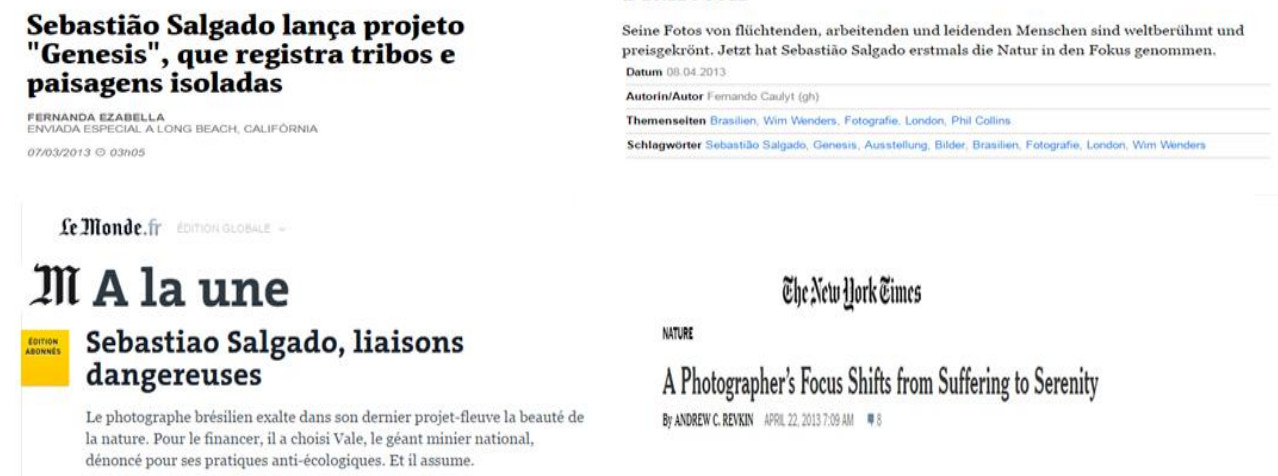

Figura 1. Os principais jornais do mundo anunciam o projeto Gênesis. Fonte: Elaborado pela autora Na coluna da esquerda: The Guardian (Reino Unido). Matéria veiculada em: 09/04/2013. Disponível em: [https://www.theguardian.com/artanddesign/2013/apr/o9/sebastiao-salgado-wildernesses-genesisexhibition]. Folha de São Paulo (Brasil). Matéria veiculada em: 07/03/2013. Disponível em: [http://www 1.folha.uol.com.br/ilustrada/2013/03/1241588-sebastiao-salgado-lanca-projeto-genesisque-registra-tribos-e-paisagens-isoladas.shtml]. Le Monde (França): Matéria veiculada em: 06/12/2013. Disponível em: [http://www.lemonde.fr/a-la-une/article/2013/12/o6/salgado-liaisonsdangereuses_3526555_3208.html\#IqJKUeo8fRGAQEp3.99]. Acesso em: Janeiro de 2017. Coluna da 
Direita: El País (Espanha). Matéria veiculada em: 19/01/2014. Disponível em: [http://cultura.elpais.com/cultura/2014/01/16/actualidad/1389900071_293824.html] Süddeutsche Zeitung (Alemanha). Matéria veiculada em: 08/04/2013. Disponível em: [http://www.dw.com/de/salgado-neue-darstellung-unseres-planeten/a-16728115]. New York Times (Estados Unidos): Matéria veiculada em: 22/04/2013. Disponível em: [http://dotearth.blogs.nytimes.com/2013/04/22/a-photographers-focus-shifts-from-suffering-toserenity/]

O único jornal que mostrou a contradição existente entre suas imagens e seus patrocínios foi o francês Le Monde. A manchete noticia: "Sebastião Salgado, ligações perigosas. O fotógrafo brasileiro ressalta em seu último projeto contínuo, as belezas naturais. Para financiá-lo, ele escolheu a Vale, a gigante da mineração nacional, criticada por suas práticas antiecológicas. E assume.”

O que é noticiado pelo jornal New York Times está totalmente de acordo com a trajetória de Sebastião Salgado. Seu trabalho tem início com uma "homenagem ao homem" (Outras Américas e Trabalhadores) e culmina com o desencanto pela espécie em Êxodos: "o homem é um animal terrível” (SALGADO, 2014), conclui ele. Há de se buscar uma redenção, voltar às origens: Gênesis. Enfim, o grande objetivo estava traçado e divulgado. Como um herói desbravador aos olhos dos espectadores que não se debruçam a compreender as histórias por trás de suas imagens, Salgado revela-nos um "novo" mundo ou um mundo que esquecemos que existe, com tribos intocadas, paisagens que parecem anestesiadas, faunas, geleiras, dunas.

No capítulo “África”, há um subcapítulo denominado "Uma viagem pelo Antigo Testamento”, onde não é apenas o nome que se refere à Bíblia, mas também a história contada pelo autor:

Em certos trechos, sabíamos que eu era o primeiro ocidental a passar por ali, as populações locais não se lembravam de algum dia terem visto um. (...) Por duas ou três vezes, quando chegamos em certas aldeias, exaustos, as mulheres vieram a nosso encontro. Elas tiraram nossos sapatos e, com um pouco de água, lavaram nossos pés. Depois os beijaram, acariciaram. Éramos como o Cristo na cena dos Evangelhos! ${ }^{10}$ Foi comovente. Sempre recebíamos presentes, comida e outros dons. Nada nos faltou ao longo de toda a viagem. Nossos dezoito burros estavam carregados com massas, cereais,

\footnotetext{
${ }^{10}$ Transcrevo aqui a nota de rodapé presente no livro: "A passagem do Evangelho chamada de Unção em Betânia (12, 1-3), João descreve Maria de Betânia lavando os pés de Jesus” (SALGADO, 2014, p. 80).
} 


\section{6:}

latas de atum, queijo processado e outros mantimentos que se conservam por meses, pois pensamos que não encontraríamos nada no local (SALGADO, 2014, p. 79).

Diante dos parcos relatos sobre lugares remotos como esse, como o autor não acreditaria ser um mensageiro trazendo a "verdade", sobretudo ao retornar à Europa para revelar seus filmes junto à equipe da Amazonas Images? Após a escolha das fotografias e feito o design da obra, a editora alemã Taschen ficou encarregada de publicar Gênesis em vários formatos, como a edição de arte e também a de colecionador. Esses exemplares vêm com uma fotografia impressa e um atril (ou leitoril. (fig. 2) projetado pelo arquiteto japonês Tadao Ando. Consiste numa pequena estante, disposta em plano inclinado onde se coloca um livro aberto para se poder ler de pé.

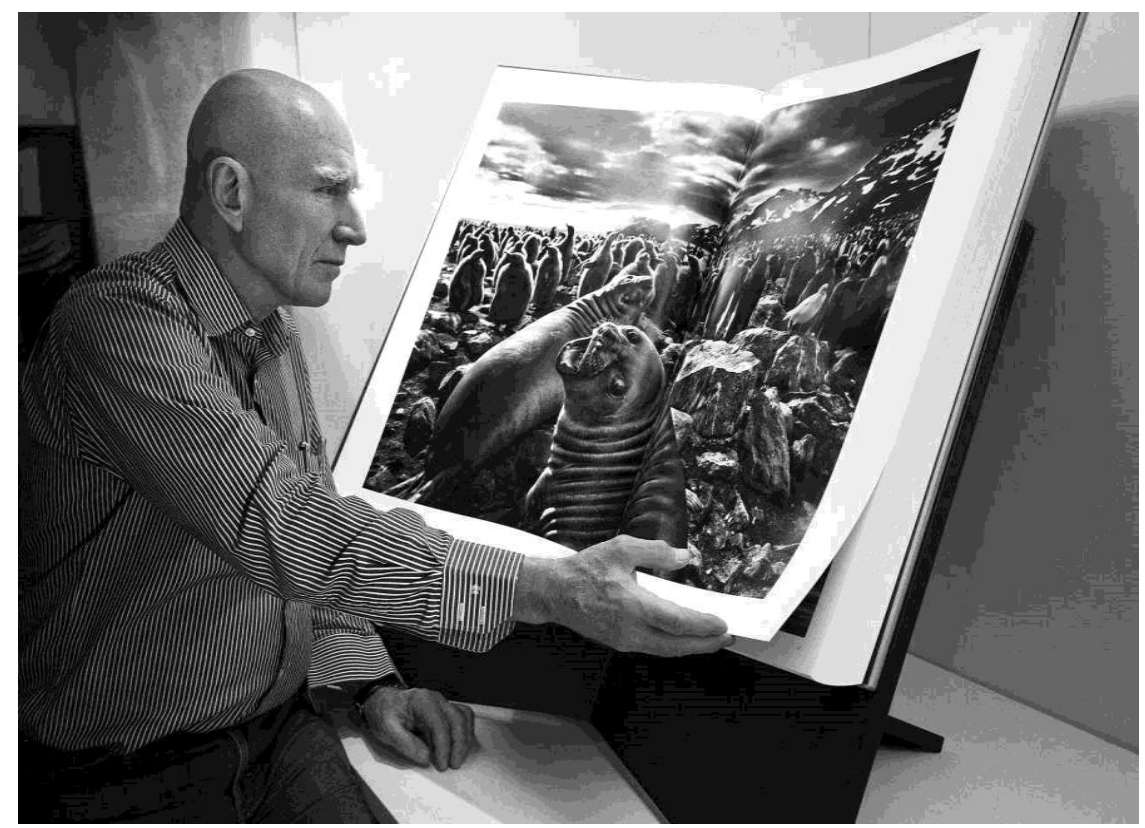

Figura 2. Sebastião Salgado e Gênesis apoiado em atril. Fonte: Revista Zum (IMS).

É notório que a característica heroica/messiânica de Sebastião Salgado prosseguiu até o momento da circulação de sua obra. As primeiras Bíblias impressas não vinham prontas e encadernadas e, por isso, eram vendidas em folhas reunidas, posteriormente encadernadas pelos compradores em grandes e imponentes tomos e, ao final, destinadas a ficarem expostas num atril (MANGUEL, 1997).

A característica messiânica de Sebastião Salgado pode ainda ser identificada em seu relato sobre os Zo’é, tribo que vive no interior da floresta amazônica, no estado do Pará. Essas fotografias fazem parte do último capítulo, “Amazônia e Pantanal”, no qual o fotógrafo dedica o primeiro subcapítulo a eles (fotograma n. 32). Especificamente no encarte a história contada por Salgado é bastante breve: 
A tribo foi contatada em 1987 pelos evangelistas americanos da New Tribes Mission. Tencionavam converter os indígenas à sua versão de cristianismo e começaram distribuindo presentes entre eles, como roupas, ferramentas e espelhos, além de construírem a primeira pista de aterrisagem da área. Mas três anos depois, a Fundação Nacional do Índio (FUNAI), responsável pela proteção dos povos indígenas, expulsou a New Tribes Mission das terras dos Zo'é. Posteriormente, a FUNAI criou a chamada Frente de Proteção Etnoambiental Cuminapanema, com a função específica de evitar outras invasões do território dos Zo’é (SALGADO, 2013. Encarte, p. 27).

Em seu livro autobiográfico, Salgado dedica mais tempo à história dos Zo’é e expõe que os jesuítas, no século XVI, já haviam mencionado em seus relatos a presença de um grupo próximo ao rio Amazonas que usava madeira para adornar os lábios, um traço bem característico. No entanto, após essa constatação dos jesuítas, ninguém mais os viu e essa tribo (termo utilizado pelo autor) tornou-se lenda até o ano de 1987, quando os missionários norte-americanos os contataram, conforme exposto acima.

Com apenas 30 anos de contato, poucos são os registros desses índios e Salgado estava preparado para fazê-los. A altíssima circulação dessas fotos pelo mundo inteiro garantiu a primazia de seu olhar sobre os Zo'é, como um criador lhes dando um 'sopro de vida'. No tocante às imagens fotográficas, dentre muitos exemplos que poderia destacar aqui, optei por selecionar as imagens dos índios fora de seu habitat, ou seja, em estúdios em meio a floresta no tempo em que as câmeras não eram instantâneas.

Ao retratar os olhares do grupos indígenas encarando a câmera e, outras vezes, fora de seu habitat, os registros de Gênesis nos remetem aos primórdios da fotografia que, como se sabe, eram utilizadas nos discursos antropológicos e, também, geográficos como ferramenta para comprovar o domínio sobre os seres ditos primitivos ou menos desenvolvidos.

Mais de 100 anos depois dos primeiros registros fotográficos, Gênesis ainda nos remete ao exótico, ao intocado. Na imagem abaixo (fig. 3) ${ }^{11}$, fruto de uma montagem das fotografias presentes na obra, apenas a primeira fotografia é de uma sociedade indígena de contato recente, os Korowai. Já acima, à direita, há o registro de um dos grupos tradicionais da Etiópia que hoje vivem em uma área preservada, o Parque Nacional de

\footnotetext{
11 A agência Amazonas Images detentora dos direitos autorais sobre uso de imagens do fotógrafo Sebastião Salgado não permitiu sua veiculação na Revista Espaço e Cultura. A montagem, referida como figura 3, pode ser visualizada na página 65 da dissertação da autora disponível no endereço digital <http://www.bdtd.uerj.br/tde_busca/arquivo.php?codArquivo=12180> (Nota dos editores). 
Omo. Embora pareçam exóticos e primitivos, constantemente entram em guerra com outra tribo, onde há o aumento crescente de armas automáticas por ambas.

A última fotografia, abaixo do lado direito, foi realizada nos Planaltos de PapuaNova Guiné, já completamente urbanizado com grande rede de estradas e economia baseada no café, chá, ouro e cobre. Esses adornos são utilizados somente em festivais, mas ao adentrar a exposição de Gênesis, fica a impressão de que todas as tribos conservaram suas tradições e vivem em lugares remotos.

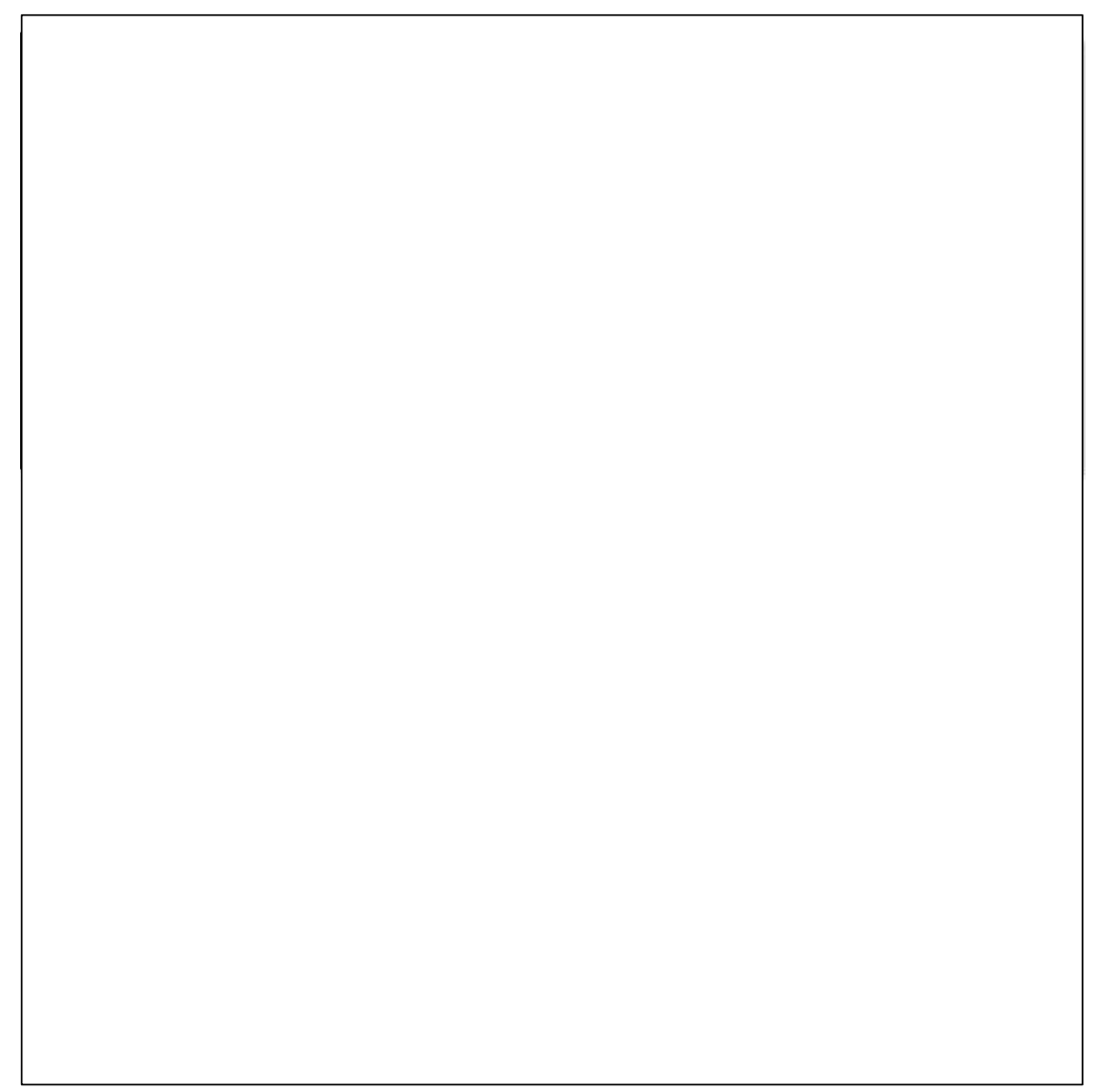

Figura $3^{12}$. Diferentes povos presentes em Gênesis. Fonte: Salgado, 2013. Adaptado pela autora. Acima à esquerda: Tribo Korowai. A maioria ainda utiliza ferramentas de pedra no seu dia a dia. Papua Ocidental, Indonésia. Fevereiro e março de 2010 (P. 139). Acima à direita: Povoação Surma durante as festividades de apresentação de jovens mulheres prontas para casar. Parque Nacional do Omo, perto de Maji. Etiópia. Setembro e outubro de 2007. Abaixo à esquerda: Membro da tribo Dinca. Sul do Sudão junto à representação simbólica de chifres na parede interna de um lar tradicional. Fevereiro e março de 2006 (P. 254). Abaixo à direita: Executante do festival singsing de Mount Hagen. Planalto Ocidental, Papua-Nova Guiné. Julho e agosto de 2008 (P. 200).

${ }^{12}$ A agência Amazonas Images detentora dos direitos autorais sobre uso de imagens do fotógrafo Sebastião Salgado não permitiu sua veiculação na Revista Espaço e Cultura. A montagem, referida como figura 3, pode ser visualizada na página 65 da dissertação da autora disponível no endereço digital <http://www.bdtd.uerj.br/tde_busca/arquivo.php?codArquivo=12180> (Nota dos editores). 
Outras práticas para além do olhar direto para a câmera se mantiveram. Uma delas consiste em dispor indígenas de maneira organizada com objetos que não fazem parte de seu habitat. À título de exemplificação, exponho aqui a pesquisa de Fernando Tacca (2011), na qual o autor revela que as primeiras imagens de índios foram realizadas na França com os Botocudo. Levados àquele país para serem apresentados em eventos científicos, a presença desses 'selvagens' causava alvoroço no meio intelectual parisiense onde eram posteriormente medidos e enquadrados nos cânones do discurso institucional da antropologia física, além de registrados pela Sociedade de Geografia (TACCA, 2011, p. 192).

Em Trésors Photographique, Loiseaux (2007) também discorre sobre as dificuldades de fazer fotografia nos anos de 1870. Ainda continuava sendo comum capturar os povos ditos selvagens para levá-los a estúdios nas grandes cidades. Foi o que fez o fotógrafo australiano John William Lindt (1845-1926) que trouxe para sua oficina um membro aborígene para posar na frente das telas pintadas, em meio a seus objetos diários e elementos de vegetação arrumados para recriar a vida dessas populações no seu ambiente natural.

A disposição das fotografias abaixo expressa distintos momentos com o objetivo de estabelecer diálogos visuais que permitam perceber sobrevivências (afertlife). A montagem ora elaborada (fig. 4) ${ }^{13}$, ressalta essas características e, principalmente, a sobrevivência (Nachleben) no modo de fazer e reproduzir a imagem do Outro, como fora apontado por Didi-Huberman (2013) a partir de seus profundos estudos sobre a obra do historiador da arte Aby Warburg. Didi-Huberman esclarece que a importância das montagens está em ligar dois momentos desconexos do tempo, fazendo de um a memória do outro. Nachleben supõe, então, uma teoria intervalar do tempo, ou melhor, uma teoria dos intervalos como constituintes do tempo (DIDI-HUBERMAN, 2013).

\footnotetext{
13 A agência Amazonas Images detentora dos direitos autorais sobre uso de imagens do fotógrafo Sebastião Salgado não permitiu sua veiculação na Revista Espaço e Cultura. A montagem realizada, referida como figura 4, pode ser visualizada na página 95 da dissertação da autora disponível no endereço digital <http://www.bdtd.uerj.br/tde_busca/arquivo.php?codArquivo=12180> (Nota dos editores). 


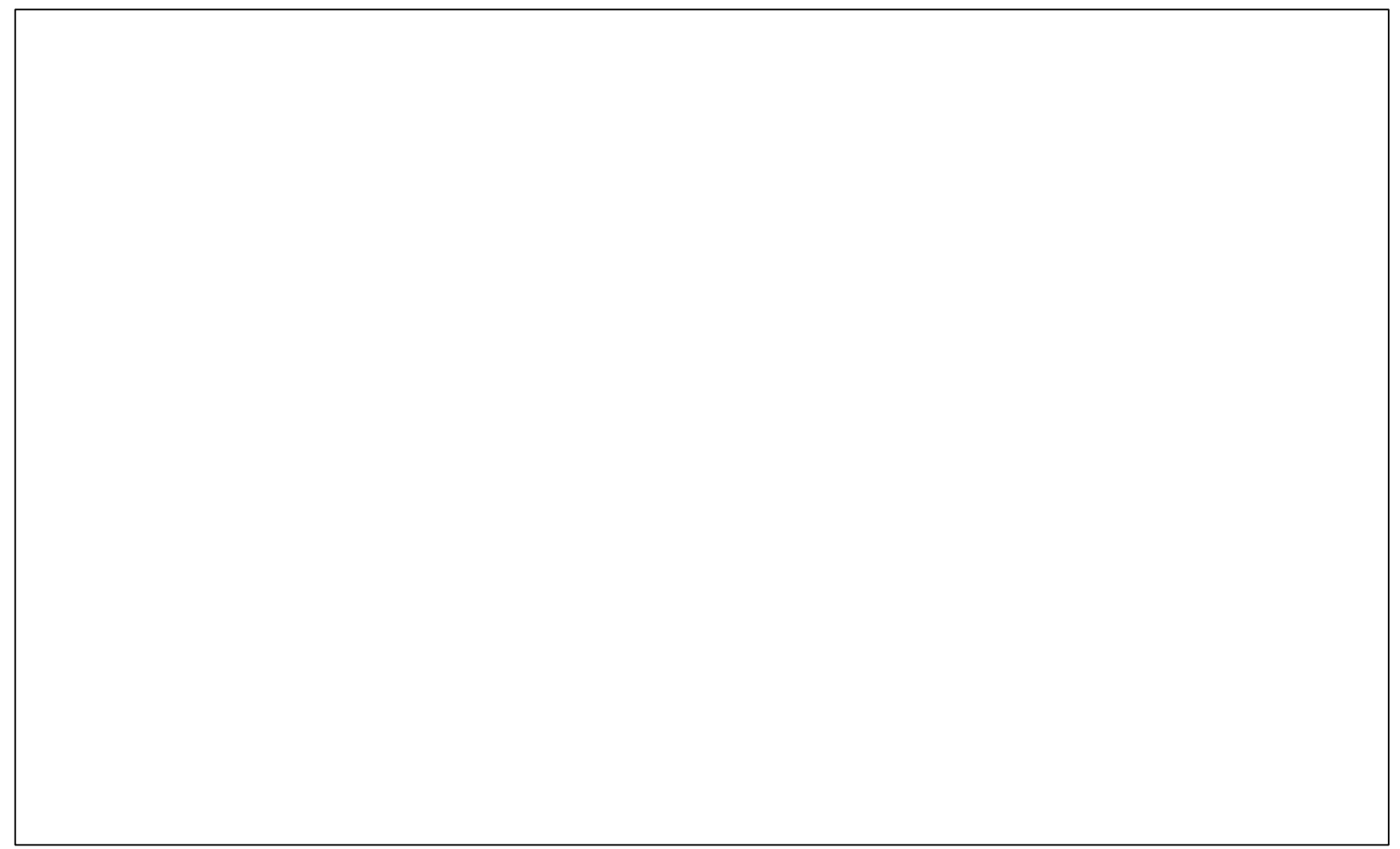

Figura 4. ${ }^{14}$ Aborígene australiano e índios em estúdio. Fonte: Elaborado pela autora. Acima à esquerda: Membro aborígene Gumbaynggirr no estúdio de John William Lindt (1845-1926). Fotografia de 18731874. Fonte: Trésors Photographique de la Société de Géographie. Disponível online: [http://expositions.bnf.fr/socgeo/grand/198.htm]. Acesso em: Janeiro de 2017. Acima à direita: índios bororo em estúdio montado em meio a floresta, no Mato Grosso, Brasil. Fotografia por Marc Ferrez, 1880. Fonte: Acervo do Instituto Moreira Salles. Abaixo: Xamãs da tribo Kamayura. Mato Grosso, região do Xingu. Brasil, 2005. Fonte: Sebastião Salgado. Gênesis, 2013.

Para compreender a fotografia do indígena deve-se ter conhecimento histórico dessa prática, pois do contrário, cairíamos na armadilha da generalização inconsistente e continuaríamos a ver na fotografia apenas o índio como exótico sem problematizá-la.

É importante destacar que certas práticas permanecem até os dias atuais. Um grande projeto como Gênesis só é posto em prática se for interessante para todos os seus patrocinadores, portanto, a viagem do explorador já nasceria com valores mercadológicos (LÉVI-STRAUSS, 1973). Lévi-Strauss afirma que ser um explorador é um comércio que não consiste, como se poderia pensar, em descobrir fatos até então desconhecidos depois de anos de estudo, mas em cobrir um grande número de quilômetros e montar lanternas [lanter-slides] ou filmes, preferencialmente em cores para encher uma sala com um público por vários dias em sucessão (LÉVI-STRAUSS, 1973 apud DRIVER, 2003, p. 1).

\footnotetext{
${ }^{14}$ A agência Amazonas Images detentora dos direitos autorais sobre uso de imagens do fotógrafo Sebastião Salgado não permitiu sua veiculação na Revista Espaço e Cultura. A montagem realizada, referida como figura 4, pode ser visualizada na página 95 da dissertação da autora disponível no endereço digital <http://www.bdtd.uerj.br/tde_busca/arquivo.php?codArquivo=12180> (Nota dos editores). 
Com argumentos e patrocinadores contraditórios, Sebastião Salgado pode ser visto como a figura do showman, típica do século XX quando a Royal Geographical Society passou a promover desafios como o chamado "Ainda Desconhecido" ("Still Unknown”), onde patrocinava expedições oficiais e ajudava entusiastas amadores.

Outro traço de sobrevivência da cultura da exploração nas práticas de Sebastião Salgado encontra-se na utilização de suas obras no meio educativo, tal como fizera Halford Mackinder. A equipe do fotógrafo, percebendo a potencialidade das imagens como material educacional, firmou junto ao SESC São Paulo e apoiado pela FFLCHUSP (Faculdade de Filosofia, Letras e Ciências Humanas da Universidade de São Paulo) o Projeto Exxodos: Programa Educacional ${ }^{15}$. Foram impressos 2.000 exemplares distribuídos gratuitamente para professores e para o Movimento Sem Terra. O material é composto por três livros, um conjunto de 15 pranchas fotográficas, mapas e cronologias.

O mesmo foi proposto para Gênesis, mas até então não teve apoio do governo brasileiro. No entanto, o material educativo de Gênesis já existe e encontra-se circulando nas Astúrias, Espanha. Consiste em um projeto de educação ambiental chamado "Génesis Asturias" ${ }^{16}$ que utiliza as fotografias do álbum para promover sensibilização e reflexões.

Analisando as fotografias de Gênesis e compreendendo a trajetória de seu autor, o contexto e a que custos elas foram feitas, é possível dizer que o álbum pode ser lido como uma clara sobrevivência da cultura da exploração, não só pelas semelhanças visuais entre algumas fotografias, mas pelas práticas envolvidas. Para compreender melhor todas elas, deve-se priorizar seus patrocínios, pois eles moldam a figura do autor e garantem a circulação da obra não só na forma de livro, como também na forma de discurso em palestras, mesas redondas, talkshows, livros autobiográficos e filmes.

\section{Considerações Finais}

A exploração certamente não terminou no século XIX. Na realidade, à medida que os horizontes geográficos se estreitavam, a exploração diversificava ainda mais, e desenvolveu conjuntos complexos de motivos, práticas e relações de poder. Há um

\footnotetext{
15 O número 1 chamado "Deslocamentos populacionais e novas formas de solidariedade" encontra-se disponível online em: [https://artedelia.files.wordpress.com/2013/08/925-m-01.pdf]. Acesso em: janeiro de 2017.
}

${ }^{16}$ Disponível em: [http://blog.educastur.es/presta/proyecto-genesis/]. Acesso em: janeiro de 2017. 
grande ritmo de exploração que está se acumulando juntamente com as fontes. Estudos mostram que novas tecnologias, teorias científicas, configurações geopolíticas e valores culturais têm mantido a exploração como uma moeda forte através do século XX e, também, no século XXI (DRIVER, 2010).

Eis aqui uma frente de pesquisa que vem se consolidando nos últimos anos visando compreender os novos espaços de exploração a partir das práticas envolvidas nas primeiras explorações geográficas. Segundo James Ryan e Simon Naylor (2010), os estudos acadêmicos sobre exploração têm sofrido uma espécie de renascença nos últimos vinte anos. A exploração e o controle de novos locais para exploração de recursos continuam a dialogar com as explorações geográficas e geológicas do século XIX e hoje não são meramente simbólicas.

As empresas mineradoras com interesses na exploração da riqueza mineral da República Democrática do Congo, por exemplo, estão agora revisitando registros cartográficos e geográficos do século XIX para ajudar a sua prospecção. Enquanto isso, as regiões polares, tão fortemente associadas às viagens heroicas dos séculos XIX e XX, estão sendo reexaminadas no contexto de tentativas de vários países para estender os direitos de soberania sobre os andares oceânicos nas prateleiras continentais adjacentes. Desta forma, a exploração poderia ser considerada menos como um meio imparcial de "descobrir" o "desconhecido" e mais como uma projeção poderosa e duradoura dos interesses imperiais do Ocidente em outras partes do mundo (NAYLOR \& RYAN, 2010)

Essas consistentes colocações de James Ryan e Simon Naylor, podem ser apropriadas aqui como uma forte crítica à viagem de Sebastião Salgado. Ao tentar buscar trazer o "desconhecido" financiado por empresas acusadas de "lavagem verde", o fotógrafo se torna cada vez mais contraditório. Seu reconhecimento mundial o possibilitaria de tecer análises mais direcionadas, no entanto, Salgado para em discursos quase que superficiais além de dar continuidade à prática da alteridade em parte das fotografias de etnias quando solicita o olhar direto para a câmera ou quando muda os cenários naturais.

\section{REFERÊNCIAS BIBLIOGRÁFICAS}

ALPERS, S. (1999) Arte de Descrever: A Arte Holandesa no Século XVII. São Paulo: Edusp. 427 p.

ANGOTTI-SALGUEIRO, H. (2005) A construção de representações nacionais: os desenhos de Percy Lau na Revista Brasileira de Geografia e outras "visões iconográficas" do Brasil moderno. Anais do museu paulista: história e cultura material, v. 13, n. 2, p. 21-72. Disponível em: < http://www.revistas.usp.br/anaismp/article/view/5426>. Acesso em 26 de agosto de 2018. 
BADGER, G. (2015) Por que fotolivros são importantes? Revista Zum [online], São Paulo: Instituto Moreira Salles, n. 8.

BARBUY, H. (1996) O Brasil vai a Paris em 1889: um lugar na Exposição Universal. Anais do Museu Paulista. v. 4. São Paulo, dez-jan., 1996. p. $211-261$.

BORGES, M. E. L. (2008) História E゚ Fotografia. 2ª ed., Belo Horizonte: Autêntica. 132 p.

DIDI-HUBERMAN, G. (2013) A imagem sobrevivente: história da arte e tempo dos fantasmas segundo Aby Warburg. Rio de Janeiro: Contraponto. 508p.

DRIVER, F. (2003) Geography Militant: Cultures of Exploration and Empire. London: Blackwell Publishers. 268 p.

Modern Explorers. In: NAYLOR, S. \& RYAN, J. (2010). New Spaces of Exploration: Geographies of discovery in the twentieth century. I.B. Tauris. p. $241-249$.

FLUSSER, V. (2011) Filosofia da caixa preta: ensaios para uma filosofia da fotografia. São Paulo, Annablume. $101 \mathrm{p}$.

LATOUR, Bruno. Cognição e visualização. Terra Brasilis (Nova Série) [Online], n.4, 2015. Disponível em: http://terrabrasilis.revues.org/1308;DOI:10.4000/terrabrasilis.1308. Acesso em 7 de maio de 2018.

LOISEAUX, O. (dir.) (2007) Trésors photographiques de la société de géographie. Paris: Bibliothèque Nationale de France/Glénat. 239 p.

MACKINDER, H. (1911) The teaching of geography from an imperial point of view, and the use which could and should be made of visual instruction. The Geographical Teacher, v. 6, n. 2, 1911. pp.79-86.

MANGUEL, A. (1997) Uma história da leitura. Tradução Pedro Maia Soares. $2^{a}$ ed. São Paulo: Companhia das Letras. 408 p.

MAUAD, A. M. (2008) O olhar engajado: a fotografia contemporânea e as dimensões políticas da cultura visual. ArtCultura, Uberlândia, v. 10, n. 16, pp. 33-50, jan-jun. Disponível em: < http://www.seer.ufu.br/index.php/artcultura/article/view/1495>. Acesso em 17 de agosto de 2018.

MITCHELL, W. J. T. (1994) Picture Theory. Chicago: University of Chicago Press. 445 p.

MUAZE, M. (2009). O Império do Retrato: fotografia e poder na sociedade oitocentista. Projeto História: Revista do Programa de Estudos pós-graduados em História, São Paulo, n. 34. pp. 169188. Disponível em: < https://revistas.pucsp.br/index.php/revph/article/view/2472 $>$. Acesso em 30 de abril de 2019.

NAYLOR, S; RYAN, J. (2010) New Spaces of Exploration: geographies of discovery in the twentieth century. London: IB Tauris. 320 p.

NOVAES, A. R. (2010) Fronteiras Mapeadas: Geografia Imaginativa das fronteiras SulAmericanas. Tese de doutorado, Rio de Janeiro, UFRJ/IGEO/PPGG. 370 p.

RYAN, J. (1997) Picturing Empire: Photography and the visualization of the British Empire. Chicago: Reaktion Book. 272 p. 
SALGADO, S.; FRANCQ, I. (2014) Da minha terra à Terra. Tradução: Julia da Rosa Simões. $1^{\text {a }}$ Ed. São Paulo: Paralela. 152 p.

SALGADO, S. (2013) Gênesis. Colônia: Taschen. 520 p. Êxodos (1999) São Paulo: Companhia das Letras. 431 p.

SCHWARTZ, J. (1996) The geography lesson: photographs and the construction of imaginative geographies. Journal of historical geography, v. 22, n.1, pp. 16-45. Disponível em: < https://www.sciencedirect.com/science/article/pii/So305748896900031> Acesso em 4 de julho de 2018.

SONTAG, S. (2004) Sobre Fotografia. São Paulo: Cia. das Letras. 224 p.

TACCA, F. (2011) O índio na fotografia brasileira. História, Ciências Sociais e Saúde Manguinhos, Rio de janeiro, v. 18, n. 1. pp. 191-223. Disponível em: < http://www.scielo.br/pdf/hcsm/v18n1/12.pdf>. Acesso em 17 de julho de 2018. 